\title{
Aspirált endodontiai eszköz eltávolítása ismételt merev bronchoscopia segítségével
}

\author{
DR. HOLHÓS NÓRA*, DR. ALBERT ISTVÁN*, DR. ZSÓLYOMI KRISZTINA*, DR. MÁRTON KRISZTINA***
}

\begin{abstract}
A szerzők célja a fogászati kezelések során előforduló idegen test aspiratiók, illetve ingestiók veszélyeire, azok elkerülésére, a bekövetkezett esemény szövődményeire és megoldási lehetőségeire felhívni a figyelmet.

72 éves férfibeteg kezelés közben egy endodontiai eszközt (36 mm hosszú (teljes hossz) K-tágító) aspirált. A fogorvos gastroenterológiai konziliumot kért, majd miután mellkas-röntgenfelvétel alapján kiderült, hogy aspiratióról van szó, a beteg a bronchologiai ambulancián jelentkezett. A beteget félig ülő helyzetben elhelyezve a pulmonológus excisorral többször megpróbálta megragadni a tárgyat, de az rendszerint kicsúszott a múszer pofái közül, majd a jobb tüdő 9-es segmentumának subsegmentjébe került, ekkor eltűnt szem elől és csaknem a rekeszfelszínig vándorolt. Mellkassebész és fogorvos kollégával történt konzílium alapján a magas infectiós és perforatiós kockázat miatt megoldásként másnapra jobb alsó lobectomia jött szóba. A kontroll bronchoscopia során azonban a pulmonológus Trendelenburg helyzetben ismételten átvizsgálta a jobb basalis szájadékokat és sikerült megragadnia a tű műanyag végét, majd azt az excisorral eltávolítania. A beteg ezután lege artis Clindamycin terápiában részesült.

A kezelő fogorvos részéről fontos, hogy ilyenkor a következőleg beavatkozó orvosi csapat kezébe kerüljön a fogászati anamnézis, a baleset leírása, és szerencsés, ha az aspirált vagy lenyelt tárgyhoz hasonlót tudunk bemutatni a helyes stratégia meghatározása, a súlyos szövődmények elkerülése érdekében. A fogászati kezelés során a rutin eljárás részeként kell szerepelnie a mútéti terület gondos izolálásának, ami alkalmas lehet az aspiratio, illetve az ingestio megelőzésére. Ezt szolgálja a kofferdam megfelelő alkalmazása, ami a legtöbb esetben egyszerủ, gyorsan és könnyen kivitelezhető múvelet.
\end{abstract}

Kulcsszavak: fogászati kezelés, idegen test, aspiratio, ingestio, endodontiai eszköz, bronchoscopia, exscisor

\section{Bevezetés}

Idegen testek aspiratioja számos esetben sürgősségi ellátást igénylő helyzet. Különösen igaz ez a fogászati kezelések során kialakuló eseményekre, hiszen minden intraorális beavatkozás annak a veszélyét rejti, hogy akár fogmaradvány, kivehető fogpótlás, fogászati fúrók, csapos fogmúvek, endodontiai eszközök, kofferdam kapocs, letört fogpótlásdarab, amalgám- vagy más tömésből származó törmelék, egyéb műszeralkatrészek kerülhetnek az emésztőrendszerbe vagy a légutakba [8].

Jelen esetismertetéssel a szerzők célja a fogászati kezelések során előforduló idegen test aspiratiok, illetve ingestiok veszélyeire, elkerülésére, a bekövetkezett esemény megoldási lehetőségeire és szövődményeire felhívni a figyelmet.

Irodalmi adatok rámutatnak, hogy az idegen testek aspiratiojában és ingestiojában több körülmény is szerepet játszik. llyenek lehetnek a beteg általános egészségi és mentális állapota, az érzéstelenítés módja, a hozzáférés nehézsége, a rálátás problémája a beavatkozást igénylő területre, de más okok is fontosak lehet- nek, így pl. a beavatkozott fog pozíciója, vagy a fogorvos klinikai tapasztalata. Általánosan igaz, hogy az ilyen típusú esetek hiányosan dokumentáltak. A lenyelt idegen testek kb. 90\%-a esemény nélkül lezajlik, míg hozzávetőleg $10 \%$-a endoscopos eltávolítást igényel, és mintegy $1 \%$ mütéti beavatkozást tesz szükségessé. Ugyanakkor a bronchoscopia 99\%-os biztonsággal lehetővé teszi az aspirált objektumok eltávolítását, a komplikációs ráta itt mintegy 2,4-5\% [8].

A fogászati kezelés során a rutin eljárás részeként kell szerepelnie a mútéti terület gondos izolálásának, különösen endodontiai beavatkozások esetén, ami alkalmas lehet az aspiratió, illetve az ingestio megelőzésére. Ezt szolgálja a kofferdam megfelelő alkalmazása, ami a legtöbb esetben egyszerü, gyorsan és könnyen kivitelezhető múvelet [3]. Sajnos, azonban a leggondosabb prevenciós eljárások ellenére is előfordulhatnak ilyen jellegű, nem várt balesetek. [9]

llyenkor a sikeres eltávolítás lehetősége függ az idegen test helyétől, helyzetétôl, a rendelkezésre álló müszerparktól, az operátor képességeitől, a beteg együttműködési készségétől [2]. 
Susini és munkatársai 2007-ben közölték francia biztosítótársaságok által rendelkezésre bocsájtott adatok alapján egy 11 évet felölelő időszakban a kofferdam izolálás nélküli endodontiai beavatkozások során történt idegen test ingestiok és aspiratiok előfordulási arányát. 24651 francia fogorvos munkáját elemezték, amelyben a balesetek évenkénti számát, típusát, a lenyelt vagy aspirált tárgy jellemzőit rögzítették. Ennek alapján 1 endodontiai eszközt aspiráltak, míg 57-et lenyeltek. Ezenfelül 43 más fogászati idegen test került a légutakba, valamint 409 a tápcsatornába. Ezek alapján 100000 esetre jutott 0,001 aspiratió és 0,12 ingestio az endodontiai beavatkozások során, szerencsére halálos komplikáció nem fordult elő [4].

Idegen test aspiratio szövődménye lehet részleges vagy teljes légúti obstrukció, respiratórikus dystress syndroma (ARDS), pneumothorax, különböző mértékű vérzés. Észre nem vett esetekben a tünetmentes beteg akár hónapokig is eltűnhet az egészségügyi látókörből, míg késői szövődményként felléphet postobstruktív pneumónia, bronchiectasia, tüdőtályog [1]. Ingestio esetén az objektum az esetek legnagyobb részében a tápcsatornán tünet nélkül áthalad. Azonban akár a légútban, akár a tápcsatornában történő perforatió, követés során észlelt retentió esetén azonnali mútéti beavatkozásra van szükség.

\section{Esetimertetés}

A 72 éves férfi beteg anamnézisében appendectomia, sérvmútétek, mélyvénás thrombosis szerepelt. Fogászati kezelés közben - saját elmondása szerint -, a „fúrófejet" lenyelte, amely miatt a fogorvos azonnal a területileg illetékes gastroenterologiai osztályra utalta és vitte, ahonnan a Jászberényi Kórház Sürgősségi Osztályára került megfigyelésre. Itt szóbeli pulmonológiai consilium történt. A Sürgősségi Ambulancián készült mellkas-rtg felvétel alapján a gerinc mellett a D7-es csigolya magasságában egy $35 \mathrm{~mm}$-es, tü alakú fémobjektum volt látható (1. kép). Miután tehát kiderült, hogy nem ingestioról, hanem aspiratioról van szó, a beteget másnap reggel mentő szállította a Mátrai Gyógyintézet Bronchológiai Ambulanciájára. A pulmonológusok nem kaptak információt arra vonatkozóan, hogy milyen kezelés közben, milyen körülmények között, és milyen eszköz került a beteg szervezetébe. A beteg panaszt nem jelzett, köhögésingere nem volt. Bronchoscopia során, amely bronchofiberoscoppal történt, a jobb oldalon az intermediusban egy kb. $3 \mathrm{~cm}$ hosszú fém csavarmenetes képlet volt észlelhető (2. kép).

$A$ beteget félig ülő helyzetben elhelyezve („dializáló szék”, amelynek a használatakor a vizsgáló a beteggel szemben áll) a bronchologus excisorral (3. kép) többször megpróbálta megragadni a fém végét, de az rendszerint kicsúszott a múszer pofái közül. Köhögés közben az idegen test elmozdult és múanyag végénél fogva lefelé vándorolt (4. kép), egészen a jobb tüdő 9-es segmentumának sub-subsegmentjébe, ekkor tűnt el szem

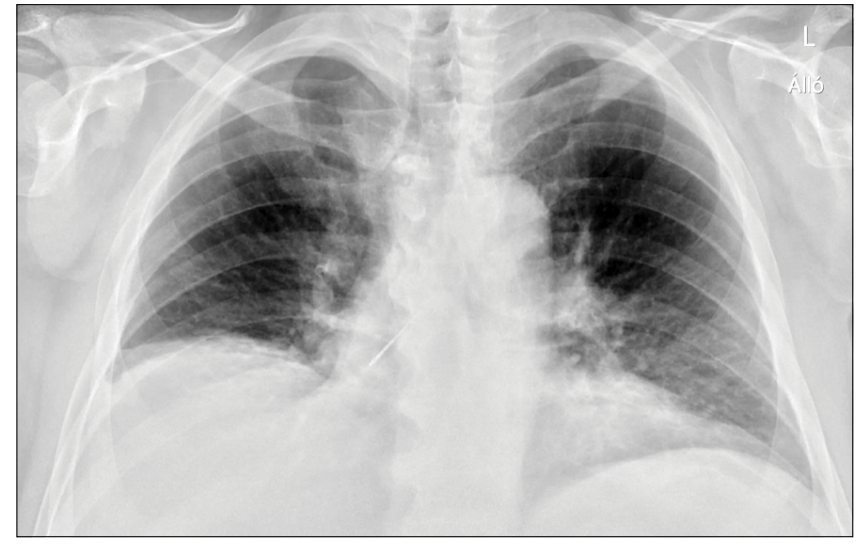

1. kép: Az eset napján az első bronchológiai beavatkozás előtt készült mellkas-röntgenfelvétel:

a gerinc mellett a D7-es csigolya magasságában egy 35 mm-es tű alakú fém idegen test látható.

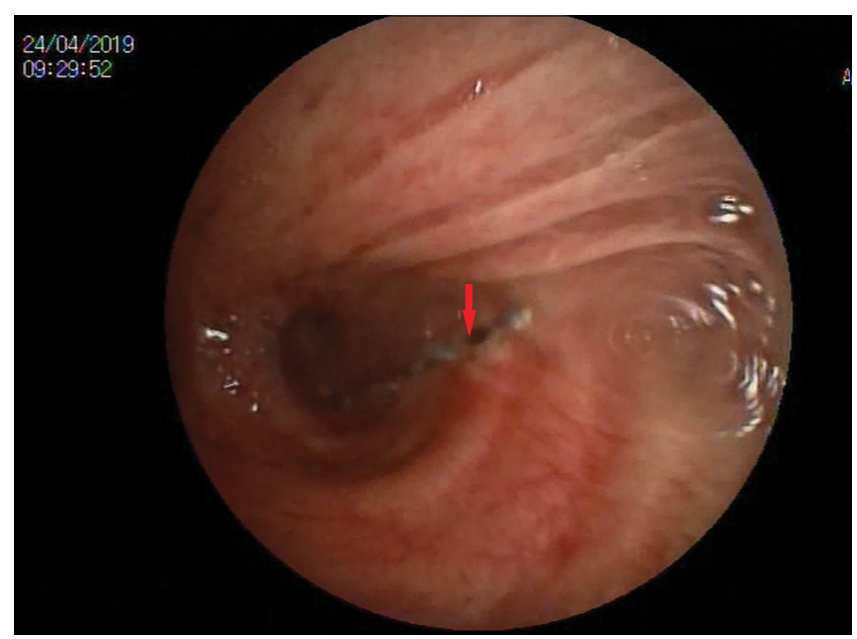

2. kép: Másnap az első bronchoscópia során a jobb oldalon az intermediusban

egy kb. $3 \mathrm{~cm}$ hosszú fém idegen test látható.

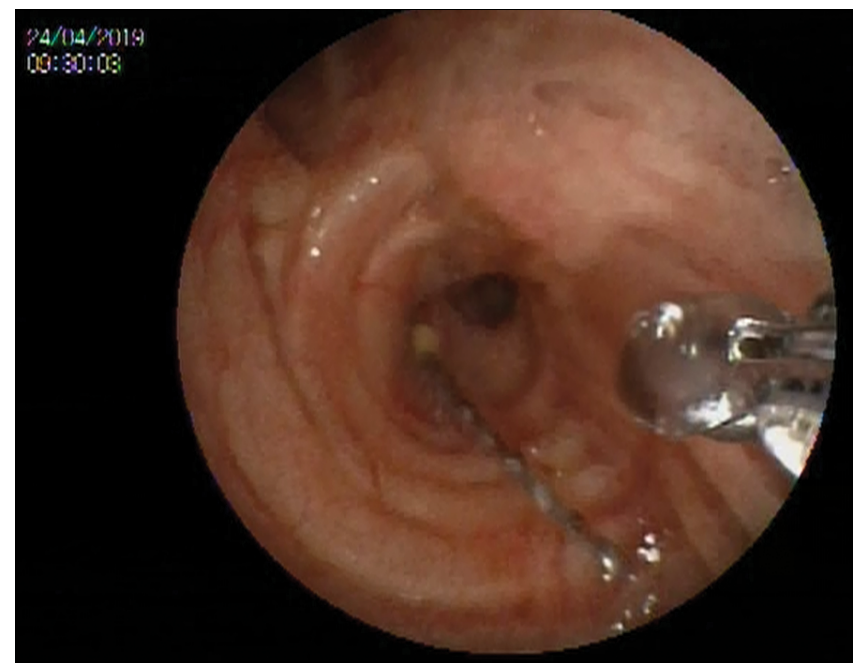

3. kép: Excisorral történő megragadás az első bronchoscópia napján. 


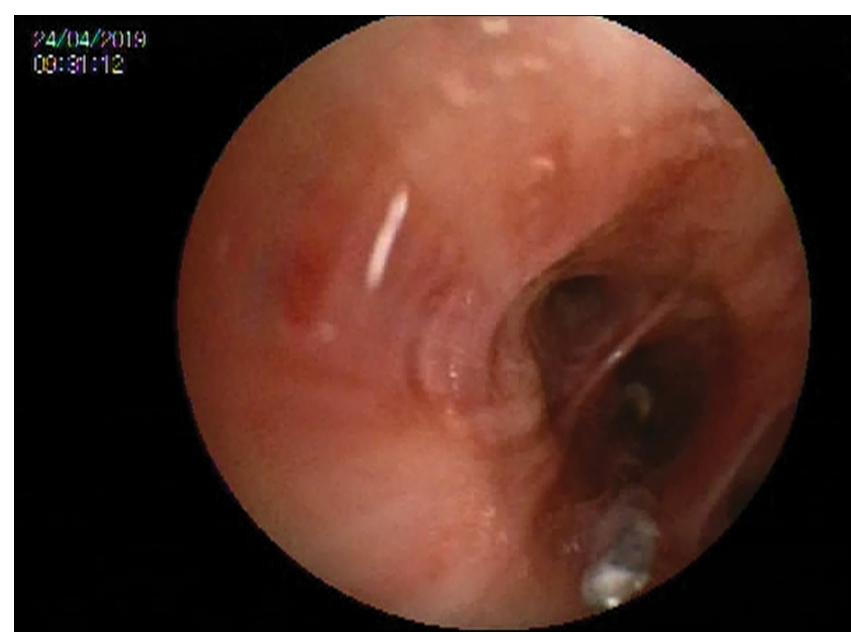

4. kép: Az első bronchoscópia alkalmával a múszer egyre lejjebb vándorolt a hörgők subsegmentalis oszlásain keresztül, végül a jobb tüdő 9-es segmentumának sub-subsegmentjében tűnt el a bronchológus szeme elől.

elől. A beavatkozásról videófelvétel készült, ami alapján másik fogorvossal történő konzultáció alapján kiderült, hogy egy $36 \mathrm{~mm}$-es (teljes hossz) K-tágító az idegen test, amely nemcsak fokozott infectiós, hanem egyben perforatiós veszélyt is jelent.

Ezt követően mellkas-CT készült, amelynek rekonstrukciós felvételein láthatóvá vált, hogy az idegen test a jobb oldalon csaknem a rekeszfelszínen ül (5. kép). A beteg megfigyelésre a Bronchológiai Osztályon maradt, obszervációja alatt semmilyen panaszt nem jelzett.

Időközben a mellkassebész kollégával történt konsilium alapján mútétet terveztek, bár magas rizikóval, mivel nyitott mútét kapcsán a tüdôt áttapintva a sebész nem tudja megtalálni az idegen testet. Ezért megoldás-

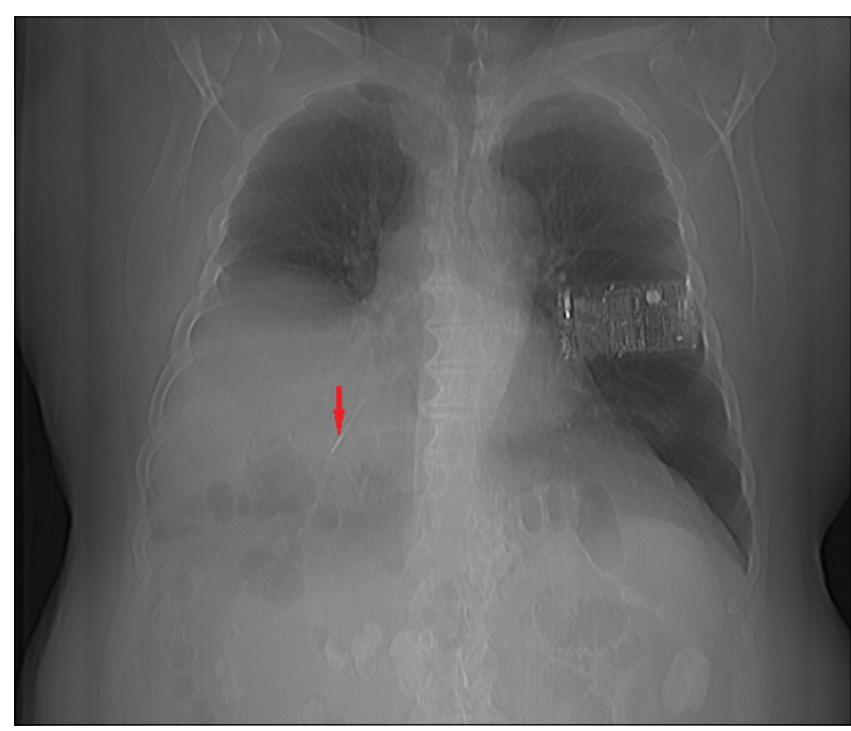

5. kép: Az eset másnapján készült mellkas-CT PA átnézeti rekonstrukciós felvétel: az első bronchológiai beavatkozás után: a műszer a jobb tüdő 9-es segmentumának sub-subsegmentjében. ként jobb alsó lobectomia jött csak szóba. A rizikó ellenére a mellkassebész másnapra vállalta a mútétet, tekintve a magas infectios kockázatot.

A tervezett mellkassebészeti áthelyezés előtt kontroll bronchoscopia történt. Ekkor a bronchológus Trendelenburg helyzetben ismételten átvizsgálta a jobb basalis szájadékokat. A 9. segment sub-subsegmentjében megpillantotta az idegen test müanyag végét (megfordult?), amelyet sikerült megragadni, így most az excisorral el lehetett távolítani.

A beteg az objektum eltávolítását követően lege artis Clindamycin terápiában részesült.

Az esetet követő tizedik napon kontroll mellkas-CT készült, amelyen intrapulmonálisan az idegen test már nem volt azonosítható (6. kép).

\section{Megbeszélés}

A leggyakoribb beágyazódási hely idegen test aspiratio esetén a jobb alsó lebeny, mint ahogy az a jelen esetben is történt [1].

Az esettel kapcsolatos tanulságok. Bronchológiai szempontból felmerülő kérdések:

Bronchológiai szempontból elsőként választandó a fém idegen testek merev bronchoscopos eltávolítása. Ennek az eljárásnak az előnye - amellett, hogy a sedalt beteg légzése kontrollálható, illetve a köhögési inger csökkenthető -, hogy a bronchoscop fém fala védelmet biztosít a további endobronchialis és hangszalagsérülésekkel szemben. Hátránya viszont, hogy ez az eszközpark nem érhető el minden bronchológiai vizsgálóban, emellett a bronchológus jártasságát igényli, valamint anaesthesiologia jelenlétét is. További hátránya, hogy ezen bronchoscopok lumen mérete miatt csak a nagyobb bron-

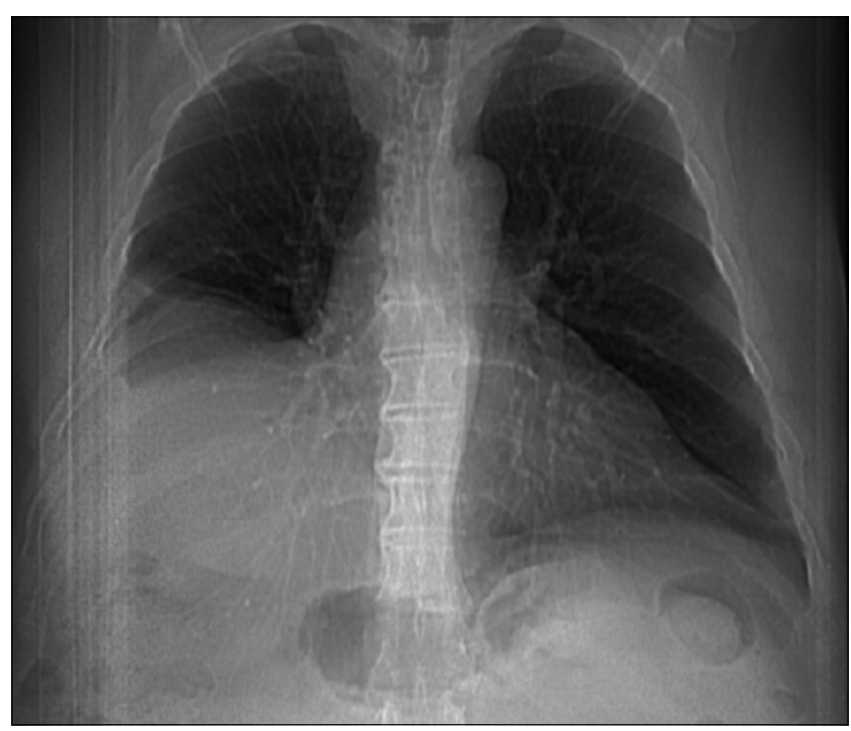

6. kép: Kontroll mellkas-CT

PA átnézeti rekonstrukciós felvétel:

a második bronchoscópia után, az eset utáni második napon: Az idegen test már nem látható. 
chusok vizsgálhatók, a fenti esetben említett sub-subsegment ágak már nem érhetők el. A fiberoscopokkal a distalisabb segmentágak is látótérbe hozhatók, de a hozzá tartozó excisorok kisebb mérete miatt a cikkben említett hosszú és vékony fém idegen testek megragadása és eltávolítása nehézkesebb. Az említett szempontok miatt fémeszköz-aspiratio gyanúja esetén érdemes merevcsöves bronchológiai eljárásokkal foglalkozó centrumokkal felvenni a kapcsolatot.

A bronchológus számára elgondolkodtató lehet, hogyan lehetséges, hogy a tǔ a szűk keresztmetszetű hörgőkben megfordul. (A beteg éjszaka feküdt, köhögött?) Ebben az esetben a várakozás ideje alatt ez történt, ami lehetővé tette a bronchoscopia sikerét a következő napon. Erre vonatkozóan nincsenek statisztikai adatok, de annyi biztos, hogy a bemutatott beteg esetében, amennyiben mégsem sikerült volna eltávolítani az endodontiai eszközt, a fém végével distalis irányba elmozduló műszer magasabb rikizót jelentett volna pneumothorax és mediastinitis kialakulása szempontjából.

További érdekes kérdés, hogy érdemes-e várni, többször kísérletezni bronchoscopiával, mielőtt sebészhez fordulnánk? Ilyenkor mindig a kockázat-haszon-arányt figyelembe véve szükséges dönteni a sebészi beavatkozásról. Jelen esetben a perforatio és további tüdő-, illetve rekeszizom-sérülés, valamint mediastinalis infectio veszélye miatt jött volna szóba mielőbbi mellkassebészeti beavatkozás, még akkor is, ha ez az egész jobb alsó tüdőlebeny eltávolításával járt volna.

Felhívjuk a figyelmet a videó-dokumentáció fontosságára. A további tanulságok és konsiliumok érdekében hasznos az endoscopia során videófelvételt készíteni. Esetünkben első alkalommal készült videófelvétel, míg a második alkalommal már nem, mivel a teljes aszszisztencia a beteggel volt elfoglalva. Az eset alapján az is megállapítható, hogy az ilyen jellegű idegen testet Trendelenburg helyzetben érdemes eltávolítani, azonban merev bronchoscopia során a distalis segment ágai nem érhetők el.

\section{Fogorvosi szempontok}

Idegen test ingestioja, illetve aspiratioja esetén két fontos aspektust kell a gyakorló fogorvosnak figyelembe vennie. Ezek a megelőzés, illetve, ha már megtörtént a baleset, akkor a további szövődmények elkerülésére tett sürgős intézkedések. Minden fogorvosnak tisztában kell lennie azzal a ténnyel, hogy azok a betegek, akik valamilyen fogászati ellátásból származó idegen testet lenyelnek vagy aspirálnak, esetenként sürgős kórházi ellátásra szorulnak. Egy korona vagy egy tompa, fogászati ellátásból származó kisebb idegen test adott esetben csökkent veszélyt jelent, de egy endodontiai eszköz, mint pl. esetünkben; vagy egy fogászati forgóeszköz vagy fogkőleszedő lepattant éles darabja komoly veszély, ezért a beteget azonnal sürgősségi osztályra kell utalni, még inkább kísérni. Amennyiben a fogorvos kevésbé súlyosnak ítéli az esetet, akkor is ez a megfelelő eljárás, még akkor is, ha az illető esetében csak követéses vizsgálatokra van szükség. A Medical and Dental Defence Union of Scotland ajánlása szerint [7] fontos, hogy ilyenkor a beteg kezében legyen a fogászati anamnézis, a történt baleset leírása, és szerencsés az is, ha az aspirált vagy lenyelt tárgyhoz hasonlót tudunk a következőleg beavatkozó orvosi csapat segítségére bemutatni. Ez nagyban hozzájárul annak eldöntéséhez, hogy a gastroenterologus, a pulmonológus, a fül-orr-gégész, vagy más beavatkozó orvos milyen stratégiát kövessen az illető objektumra vonatkozóan. Ez lehet pl. a megfigyelés és várokozás helyzete, vagy azonnali operatiót igénylő körülmény. A fogorvosnak minden ilyen esetben fel kell tüntetnie a beteg dokumentációjában, hogy mi történt, és milyen beavatkozásokat végzett el a balesettel kapcsolatosan. Ezenkívül rögzíteni kell a beteg beutalásának, illetve a sürgősségi osztályra juttatásának módját és idejét is, a mentővel való szállítás lehetőségét, illetve tényét. Mint az a 7. képen látható, fogorvosok számára egyértelmú, hogy az aspirált objektum egy endodontiai beavatkozásból származó eszköz, egy 50-es méretű K-tágító volt. A Semmelweis Egyetem Fogorvostudományi Karán a konzerváló fogászat és endodontia tantárgy oktatása során a hallgatók egyértelmü információt kapnak arról, hogy milyen beavatkozások során kötelező abszolút izoláció alkalmazása, és ezt gyakorlati munkájuk során be is gyakorolják. Ilyen beavatkozások: régi amalgámtömés eltávolítása, kompozit tömés készítése, gyökérkezelés, barázdazárás, adhezív betétek és rögzített fogpótlások beragasztása. Ajánlott alkalmazni fogfehérítés, polírozás, intraorális homokfúvó alkalmazása, leplezés javítása, fluoridálás esetén [5]. Vannak azonban olyan kezelési helyzetek, amikor a kofferdam izolálás nem megszokott. Ilyen esetekre Ismael és munkatársai a követekező preventív eljárásokat javasolják, különösen idős betegek esetén: géz elhelyezése az oropharynx „lezárására”, fogselyem vagy varróanyag kikötése kisméretű müszerek rögzítésére, pl. az operátor ujján lévő gyúrühöz. Ülő helyzet előnyösebb a nehezen hozzáférhető területek kezelésénél [6]. Ajakrektraktor alkalmazása két neodymium mágnes segítségével szintén segíthet mágnesezhető műszerek oesophagusba vagy tracheába jutásának megakadályozásában [6].

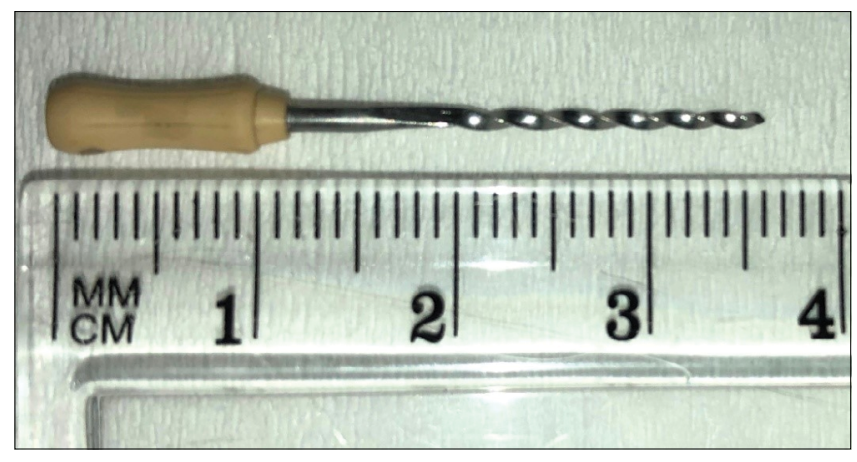

7. kép: Az eltávolított K-tágító 


\section{Irodalom}

1. Başoglu OK, Buduneli N, Cagirici U, Turhan K, Aysan Tí: Pulmonary aspiration of a two-unit bridge during a deep sleep. J Oral Rehabil. 2005; 32: 461-463. https://doi.org/10.1111/j.1365-2842.2005.01472.x

2. Cameron SM, Whitlock WL, TABOR MS: Foreign body aspiration in dentistry: a review. J Am Dent Assoc. 1996; 127: 1224-1228. https://doi.org/10.14219/jada.archive.1996.0415

3. European Society of Endodontology. Quality guidelines for endodontic treatment: consensus report of the European Society of Endodontology. International Endodontic Journal. 2006; 39: 921930. https://doi.org/10.1111/j.1365-2591.2006.01180.x

4. Guy Susini, Ludovic Pommel, J. J. Moll Camps: Accidental ingestion and aspiration of root canal instruments and other dental foreign bodies in a French population. International endodontic journal. 2007; 40: 585-589. https://doi.org/10.1111/j.1365-2591.2007.01249.x
5. GYŐRFI A: A fogak izolálása. In FAZEkAs Á. (szerk.): Megtartó fogászat és endodontia. Semmelweis Kiadó, Budapest, 2006; 123-125.

6. Ismael G, Alameida L, Lacerada T and Lacerada S: Prevention from swallowing or aspiration in dentistry for elderly patients. MOJ Gerodontology and Geriatrics. 2018; 3: 124-126. https://doi.org/10 $.15406 /$ mojgg.2018.03.00097

7. Renton C: Dangers of swallowing dental instruments. British Dental Journal. 2015; 219: 474. https://doi.org/10.1038/sj.bdj.2015.874

8. RuI H, Hongzhi Z, KaiJin H, Yuxiang D, Xia Y, Guanguie X, et al: Thorough documentation of the accidental aspiration and ingestion of foreign objects during dental procedure is necessary: review and analysis of 617 cases. Head Face Med. 2016; 12: 23. https://doi.org/10.1186/s13005-016-0120-2

9. Thakral A., Sen S., Singh VP, Ramakrishna N., Mandlik VB: Aspiration of an endodontic file. Med J Armed Forces India. 2015; 71 (Suppl 2): S509-S511. https://doi.org/10.1016/j.mjafi.2013.09.009

Holmós N, Albert I, Zsólyomi K, Márton K

\section{Accidental aspiration of an endodontc reamer and its removal via repeated bronchoscopy}

Aim of this case report is to draw attention to the danger and prevention of aspirated or ingested foreign bodies in the oral health care environment, furthermore it emphasizes the issues, the consequences and the possible solutions of these kind of accidents.

Seventy-two-year-old male patient aspirated a $36 \mathrm{~mm}$ long endodontic K-reamer during endodontic treatment. The dentist had referred him to the gastroenterology department, then at the emergency section aspiration could be evidenced according to a chest-radiograph. The patient was then transported to the bronchology ambulance. Since the needle end could not be grasped by the exsicor during the bronchoscopy process, the instrument could not be removed by the pulmonologist, for the first time, so it slid down to the subsegments of the pulmonary segment 9 , until it almost reached the diaphragm surface and disappeared from the practitioner's eye. According to consultation with a thoracic surgeon and the dentist, the pulmonology team decided a lower left lobectomy on the following day, considering the increased risk of perforation and infection. During the control bronchoscopy on the next day, the patient was laid in Trendelenburg position, while the specialist was able to remove the endodontic instrument with the exscisor. In the meantime, the needle had been turned upside down, showing its plastic end, which made the intervention successful. Patient was then provided by a "lege artis" Clindamycin therapy.

Authors would like to emphasize that the patient in these situations should be followed by the dentist until the final solution: it is crucial that dental history, description of the accident, information about the aspirated or ingested instrument should be provided to the following medical team in order to be successfully help the patient and be able to prevent further dangerous consequences. Proper isolation of the operation field is essential and must be a part of a routin dental treatment procedure. In this way ingestion and aspiration can be easily avoided. For this aim rubber-dam isolation is the most suitable tool in the dental healthcare procedures.

Keywords: oral health care, foreign body, aspiration, ingestion, endodontic instrument, bronchoscopy, exscisor 